\title{
Genetic Relatedness of Bordetella Species as Determined by Macrorestriction Digests Resolved by Pulsed-Field Gel Electrophoresis
}

\author{
M. N. KHATTAK AND R. C. MATTHEWS* \\ Pertussis Reference Laboratory and Department of Medical Microbiology, Manchester University Medical \\ School, Stopford Building, Oxford Road, Manchester M13 9PT, United Kingdom
}

\begin{abstract}
The genetic relatedness of the three medically important Bordetella species was examined by macrorestriction digestion of DNA with the rarely cutting enzyme $X b a I$ and resolution by pulsed-field gel electrophoresis. Our data showed that Bordetella pertussis, Bordetella parapertussis, and Bordetella bronchiseptica produced species-specific macrorestriction profiles and that there was some variation between different isolates of the same species. Conserved bands at 130 and $155 \mathrm{~kb}$ occurred with $B$. pertussis (130 isolates tested), but the nine variable bands between 200 and $412 \mathrm{~kb}$ distinguished 21 types. The 10 isolates of $B$. parapertussis tested produced up to 11 bands at 118 to $375 \mathrm{~kb}, 4$ of which were variable, giving three types. The eight $B$. bronchiseptica isolates examined produced up to 16 bands at 118 to $394 \mathrm{~kb}, 11$ of which were variable, giving three types. The results of this work are compared with the results of previous DNA-DNA hybridization and multilocus enzyme electrophoresis studies which suggested that these three species are closely related and should be considered members of the same species.
\end{abstract}

The following three medically important Bordetella species have been described: Bordetella pertussis, which causes whooping cough in humans; Bordetella parapertussis, the agent which can be responsible for a mild whooping coughlike disorder in humans; and Bordetella bronchiseptica, an animal respiratory pathogen which is very rarely isolated from humans. These are serologically related bacteria with similar morphologies, sizes, and staining reactions (3). They can be differentiated on the basis of their cultural characteristics, nutritional requirements, biochemical activities, and ranges of surface antigens (12).

For in vitro culture from nasopharyngeal secretions, $B$. pertussis is grown on a medium such as cephelexin charcoal blood agar, on which it produces small, shiny colonies. $B$. pertussis is a slowly growing, nonmotile organism that produces oxidase and catalase. The urease test is negative. $B$. parapertussis grows well on blood agar and nutrient agar and is nonmotile. Urease is produced after $24 \mathrm{~h}$. Catalase is produced, while oxidase is not produced. $B$. bronchiseptica grows as glistening beta-hemolytic colonies on blood agar. This organism is motile, urease is produced after $4 \mathrm{~h}$, and oxidase and catalase tests are positive. All three species ferment glucose and lactose with acid production (2).

DNA-DNA hybridization (7) and multilocus enzyme electrophoresis studies (10) have shown that these three species are closely related. It has been suggested that they should be considered members of a single species. Restriction fragment length polymorphism, generated by frequently cutting enzymes, has been described as a highly discriminatory system for determining phylogenetic relationships among isolates of the same species and related species (14). This technique failed to discriminate among isolates of $B$. pertussis, $B$. parapertussis, and $B$. bronchiseptica when DNAs were cut with EcoRI; the three organisms were indistinguishable (data not shown).

Pulsed-field gel electrophoresis (PFGE) provides an alternative tool for analyzing relationships among strains and

\footnotetext{
* Corresponding author.
}

species by facilitating the study of large fragments of DNA $(1,8)$. This technique was used to examine $B$. parapertussis and $B$. bronchiseptica and their relationship to $B$. pertussis. The chromosomal DNAs of $B$. parapertussis and $B$. bronchiseptica were digested with the rarely cutting restriction enzyme $X b a \mathrm{I}$, and the DNA fragments were resolved by PFGE. The restriction fragment patterns of these organisms were compared with each other and with the patterns of $B$. pertussis isolates obtained in this and a previous study (6) in which an analysis of 105 isolates distinguished 17 DNA types identified by PFGE on the basis of 8 to 11 intense bands at 200 to $412 \mathrm{~kb}$. A characteristic fingerprint for $B$. pertussis was defined on the basis of these predominant bands. We were able to differentiate the three Bordetella species, and each organism produced a species-specific fingerprint.

\section{MATERIALS AND METHODS}

Isolates. A total of 25 isolates of $B$. pertussis (Table 1 ), 10 isolates of $B$. parapertussis, and 8 isolates of $B$. bronchiseptica (Table 2) were examined. Isolates were obtained from the Manchester University Collection of Bacteria (MUCOB). Species were identified by Gram staining, cultural characteristics $(B$. bronchiseptica produces visible colonies after overnight incubation on nutrient agar, $B$. parapertussis produces a brown diffusible pigment after 2 days, and $B$. pertussis does not grow), and slide agglutination with rabbit polyvalent species-specific antiserum $(11,13)$. B. bronchiseptica was further characterized by its motility, its production of an obvious alkaline reaction in Hugh-Leifson medium, and its rapid hydrolysis of urea. B. pertussis vaccine strain 3700 was the control used for preparation of chromosomal DNA and molecular weight DNA markers previously sized by comparison with a bacteriophage lambda DNA ladder (Promega) (6).

Growth of bacteria. Freeze-dried cultures of $B$. pertussis, $B$. parapertussis, and $B$. bronchiseptica were suspended in $100-\mu l$ portions of sterile nutrient broth; these preparations were plated on charcoal blood agar, nutrient agar, and blood agar plates, respectively. The plates were incubated for $48 \mathrm{~h}$ 
TABLE 1. B. pertussis strains used in this study

\begin{tabular}{llc}
\hline Isolate & Serotype(s) & Year isolated \\
\hline $11 / 48$ & 1,2 & 1948 \\
$12 / 48$ & $1,2,3$ & 1948 \\
$13 / 48$ & 1,3 & 1948 \\
& & \\
2893 & 1,2 & 1955 \\
2991 & 1,2 & 1955 \\
3771 & $1,2,3$ & 1955 \\
$4 / 55$ & $1,2,3$ & 1955 \\
& & \\
$66 / 4$ & $1,2,3$ & 1967 \\
$57 / 6$ & $1,2,3$ & 1967 \\
$66 / 7$ & 1,3 & 1967 \\
$57 / 3$ & 1,3 & 1967 \\
$66 / 7$ & 1 & 1967 \\
& & \\
$11 / 9$ & 1,2 & 1968 \\
$3 / 8$ & $1,2,3$ & 1968 \\
$11 / 10$ & 1,3 & 1968 \\
S/2 & 1 & 1968 \\
$489 / 12$ & 1,2 & \\
$70 / 6$ & 1,2 & 1970 \\
$489 / 123$ & $1,2,3$ & 1970 \\
$70 / 5$ & $1,2,3$ & 1970 \\
$489 / 13$ & 1,3 & 1970 \\
$70 / 2$ & 1,3 & 1970 \\
D25/14 & 1,2 & 1970 \\
D25/12 & $1,2,3$ & 1980 \\
D25/13 & 1 & 1980 \\
\hline
\end{tabular}

at $37^{\circ} \mathrm{C} . B$. pertussis isolates were identified by their colonial morphology on charcoal blood agar, Gram staining, and serotyping with monospecific agglutinating sera prepared at the Pertussis Reference Laboratory as previously described (11). B. parapertussis isolates were identified on the basis of production of brown pigmentation on nutrient agar plates, while $B$. bronchiseptica produced glistening beta-hemolytic colonies on blood agar plates.
A colony of each isolate was resuspended and grown for $48 \mathrm{~h}$ at $37^{\circ} \mathrm{C}$ in $25 \mathrm{ml}$ of modified Stainer-Scholte broth (5) with vigorous shaking. This synthetic medium supplemented with heptakis (2,6-O-dimethyl) $\beta$-cyclodextrin (catalog no. H6379; Sigma) is a significant growth stimulant. The cells were harvested by centrifugation at $4,000 \mathrm{rpm}$ for $10 \mathrm{~min}$. The resulting pellets were resuspended in $10-\mathrm{ml}$ portions of $50 \mathrm{mM}$ EDTA ( $\mathrm{pH} \mathrm{8.0)}$ ), the preparations were centrifuged at $4,000 \mathrm{rpm}$ for $10 \mathrm{~min}$, and the turbidity, measured at $600 \mathrm{~nm}$, was adjusted to an optical density of 1.5 in $50 \mathrm{mM}$ EDTA ( $\mathrm{pH} 8.0)$.

Chromosomal DNA preparations. In order to prevent shearing of high-molecular-weight DNA, 1-ml portions of the cell suspensions described above were mixed with equal volumes of $2 \%$ low-temperature-gelling molten agarose. Each cell suspension-agarose mixture was dispensed into a 10-plug mold (Bio-Rad). The plugs were allowed to solidify at $4^{\circ} \mathrm{C}$ for $10 \mathrm{~min}$. Each plug was divided into four blocks with a clean glass coverslip.

For each strain, eight blocks were incubated overnight with shaking at $37^{\circ} \mathrm{C}$ in a sterile screw-cap bottle containing $5 \mathrm{ml}$ of EC lysis buffer ( $6 \mathrm{mM}$ Tris- $\mathrm{HCl}$ [pH 7.5], $1 \mathrm{M}$ sodium chloride, $100 \mathrm{mM}$ EDTA [pH 8.0], 0.5\% [wt/vol] Brij 58 [Sigma], 0.2\% [wt/vol] sodium deoxycholate [BDH], 0.5\% [wt/vol] $N$-lauryl sarcosine [Sigma], $1 \mathrm{mg}$ of lysozyme (Sigma) per $\mathrm{ml}, 20 \mathrm{mg}$ of RNase [Sigma] per ml) to disrupt the cell wall and membrane. Subsequently, lysis buffer was substituted for $3 \mathrm{ml}$ of ESP solution (0.5 M EDTA [pH 9.0], $1 \%$ [wt/vol] $N$-lauryl sarcosine, $1 \mathrm{mg}$ of proteinase $\mathrm{K}$ per $\mathrm{ml}$ ) for $48 \mathrm{~h}$ at $50^{\circ} \mathrm{C}(15)$. The blocks were washed for at least 15 min three times in $3 \mathrm{ml}$ of $50 \mathrm{mM}$ EDTA ( $\mathrm{pH} \mathrm{8.0)}$ and stored at $4^{\circ} \mathrm{C}$ until they were used.

Restriction digestion of chromosomal DNA. Prior to restriction digestion of the chromosomal DNA, dialysis was necessary to eliminate the cell debris and proteinase $\mathbf{K}$ activity, as well as EDTA and detergents. The presence of trace amounts of these substances interferes with restriction endonuclease digestion (16). The DNA blocks were first treated with $5 \mathrm{ml}$ of TE buffer $(10 \mathrm{mM}$ Tris- $\mathrm{HCl}$ [pH 7.5], 1 mM EDTA [ $\mathrm{pH} 8.0]$ ) containing $1 \mathrm{mM}$ phenylmethylsulfonyl fluoride for $2 \mathrm{~h}$ at room temperature to completely inactivate

TABLE 2. B. parapertussis and B. bronchiseptica isolates used in this study

\begin{tabular}{|c|c|c|c|c|}
\hline Species & Isolate & Geographic location & $\begin{array}{c}\text { Year } \\
\text { isolated }\end{array}$ & Serotype \\
\hline B. parapertussis & $\begin{array}{l}9718 \\
6890 \\
\text { MUCOB } 76 \\
\text { PP10 } \\
\text { M/S180 } \\
\text { M93 } \\
\text { MUCOB } 70 \\
\text { BR18 } \\
\text { 7283DK } \\
\text { PP145 }\end{array}$ & $\begin{array}{l}\text { Manchester, United Kingdom } \\
\text { Manchester, United Kingdom } \\
\text { Manchester, United Kingdom } \\
\text { Manchester, United Kingdom } \\
\text { Manchester, United Kingdom } \\
\text { Manchester, United Kingdom } \\
\text { United States } \\
\text { Australia } \\
\text { Copenhagen, Denmark } \\
\text { Czechoslovakia }\end{array}$ & $\begin{array}{l}1980 \\
1990 \\
1948 \\
1955 \\
1967 \\
1969 \\
-{ }^{a} \\
- \\
-\end{array}$ & \\
\hline B. bronchiseptica & $\begin{array}{l}\text { MUCOB } 9 \\
\text { MUCOB } 241 \\
\text { MUCOB } 4 \\
\text { BB3 } \\
\text { MUCOB } 74 \\
8 \\
73 \\
8760 / 52\end{array}$ & $\begin{array}{l}\text { Copenhagen, Denmark } \\
\overline{\text { Manchester, United Kingdom }} \\
\text { Manchester, United Kingdom } \\
\text { - } \\
= \\
-\end{array}$ & $\begin{array}{l}1948 \\
1948\end{array}$ & $\begin{array}{l}\mathrm{c} \\
\mathrm{d} \\
\mathrm{c} \\
\mathrm{c} \\
\mathrm{d} \\
\mathrm{d} \\
\mathrm{d} \\
-\end{array}$ \\
\hline
\end{tabular}

${ }^{a}-$, unknown. 
TABLE 3. Characterization of the 21 DNA types found in 130 isolates of $B$. pertussis

\begin{tabular}{|c|c|c|c|c|c|c|c|c|c|c|c|c|}
\hline \multirow{2}{*}{$\begin{array}{l}\text { DNA } \\
\text { type }\end{array}$} & \multicolumn{11}{|c|}{ Sizes of DNA fragments ${ }^{a}$} & \multirow{2}{*}{$\begin{array}{l}\text { No. of } \\
\text { isolates }\end{array}$} \\
\hline & $\begin{array}{l}412 \\
\mathrm{~kb}\end{array}$ & $\begin{array}{c}340 \\
\mathrm{~kb}\end{array}$ & $\begin{array}{l}315 \\
\mathrm{~kb}\end{array}$ & $\begin{array}{l}280 \\
\mathrm{~kb}\end{array}$ & $\begin{array}{l}271 \\
\mathrm{~kb}\end{array}$ & $\begin{array}{l}256 \\
\mathrm{~kb}\end{array}$ & $\begin{array}{c}240 \\
\mathrm{~kb}\end{array}$ & $\begin{array}{l}224 \\
\mathrm{~kb}\end{array}$ & $\begin{array}{c}200 \\
\mathrm{~kb}\end{array}$ & $\begin{array}{l}155 \\
\mathrm{~kb}\end{array}$ & $\begin{array}{l}130 \\
\mathrm{~kb}\end{array}$ & \\
\hline 1 & + & - & + & + & + & + & - & + & + & + & + & 40 \\
\hline 2 & + & - & + & + & - & + & - & $-{ }^{b}$ & + & + & + & 12 \\
\hline 3 & - & - & + & + & + & + & + & + & DB & + & + & 20 \\
\hline 4 & $-^{c}$ & - & + & + & + & - & + & + & DB & + & + & 4 \\
\hline 5 & - & + & + & + & + & - & + & + & + & + & + & 9 \\
\hline 6 & + & + & + & + & + & + & - & + & + & + & + & 3 \\
\hline 7 & + & + & $-{ }^{d}$ & + & $-^{e}$ & - & - & + & + & + & + & 1 \\
\hline 8 & + & + & + & + & - & + & + & - & + & + & + & 4 \\
\hline 9 & + & - & + & + & + & + & - & - & DB & + & + & 8 \\
\hline 10 & + & + & + & + & + & + & + & + & + & + & + & 9 \\
\hline 11 & $-^{c}$ & - & + & + & - & + & + & + & + & + & + & 3 \\
\hline 12 & + & - & + & - & + & + & - & - & DB & + & + & 4 \\
\hline 13 & + & + & + & + & - & + & - & + & + & + & + & 2 \\
\hline 14 & + & - & $+^{f}$ & + & - & + & - & $-b$ & + & + & + & 1 \\
\hline 15 & $-c$ & - & - & + & + & + & + & + & + & + & + & 1 \\
\hline 16 & + & - & + & + & - & - & - & + & $t^{g}$ & + & + & 1 \\
\hline 17 & + & + & $+^{f}$ & + & - & - & - & + & + & + & + & 1 \\
\hline 18 & + & - & + & + & + & + & - & + & - & + & + & 3 \\
\hline 19 & + & - & + & + & - & + & - & + & + & + & + & 2 \\
\hline 20 & + & - & + & + & - & + & $-^{h}$ & + & + & + & + & 1 \\
\hline 21 & + & - & + & + & - & - & - & + & + & + & + & 1 \\
\hline
\end{tabular}

${ }^{a}+$, band present; - , band absent; DB, double band.

${ }^{b}$ Band occurs at $215 \mathrm{~kb}$.

${ }^{c}$ Band occurs at $375 \mathrm{~kb}$.

${ }^{d}$ Band occurs at $297 \mathrm{~kb}$.

e Band occurs at $275 \mathrm{~kb}$

${ }^{f}$ An extra band is present at $297 \mathrm{~kb}$.

${ }^{g}$ An extra band is present at $178 \mathrm{~kb}$.

${ }^{h}$ Band occurs at $244 \mathrm{~kb}$.

the proteinases present in the lysis solution (8). The agarose blocks were then washed three times ( $15 \mathrm{~min}$ each time) in TE buffer without phenylmethylsulfonyl fluoride. For each strain three blocks were transferred to a microcentrifuge tube and equilibrated in $300 \mu \mathrm{l}$ of $X b a \mathrm{I}$ reaction buffer for 20 min on ice. Subsequently, $25 \mathrm{U}$ of restriction enzyme $X b a \mathrm{I}$ (Northumbria Biologicals) was added, and digestion was carried out overnight at $37^{\circ} \mathrm{C}$. The reaction was stopped by the addition of $0.5 \mathrm{ml}$ of $50 \mathrm{mM}$ EDTA (pH 8.0).

PFGE. PFGE was performed with a CHEF-DRII system (Bio-Rad). The gels $(13$ by $13 \mathrm{~cm})$ were made up of $1 \%$ agarose in TBE buffer $(10.3 \mathrm{~g}$ of Tris- $\mathrm{HCl}$ per liter, $5.5 \mathrm{~g}$ of boric acid per liter, $0.93 \mathrm{~g}$ of EDTA 0.93 per liter). The agarose blocks were loaded into wells along with $B$. pertussis vaccine strain 3700 DNA, which was used as molecular weight marker DNA. Electrophoresis was performed with a pulse time of $25 \mathrm{~s}$ for $40 \mathrm{~h}(16)$ and with a field strength of 4.5 $\mathrm{V} / \mathrm{cm}$. The gels were stained with $0.5 \mu \mathrm{g}$ of ethidium bromide per $\mathrm{ml}$ in $300 \mathrm{ml}$ of distilled water for $20 \mathrm{~min}$; this was followed by destaining for $3 \mathrm{~h}$ in distilled water. The gels were photographed under a UV transilluminator.

\section{RESULTS}

Macrorestriction fingerprinting by PFGE combined clear and reproducible resolution of restriction fragments with demonstration of a high degree of polymorphism. When the DNAs of 25 isolates of $B$. pertussis were cut with $X b a \mathrm{I}, 8$ to 11 large fragments in the size range from 130 to $412 \mathrm{~kb}$ and multiple fragments smaller than $110 \mathrm{~kb}$ were generated. Fragment bands at 130 and $155 \mathrm{~kb}$ were conserved. Differentiation was based on variable bands at $200,224,240,256$,
$271,280,315,340$, and $412 \mathrm{~kb}$. DNA type 1 was the most common DNA type, as found in the previous study (6); 17 of the 25 isolates had this DNA type. DNA type 2 was found in only one isolate. Four new DNA types were observed. These were designated DNA types 18, 19, 20, and 21 (Table 3 ). Three isolates had DNA type 18 , while two isolates had DNA type 19 . DNA types 20 and 21 were each found in one isolate. The results for these 25 isolates are compared with the results obtained previously (6) in Table 3 , and the profiles of DNA types 1 through 5 and 9 are illustrated in Fig. 1.

Restriction digestion of the DNAs of the $B$. parapertussis

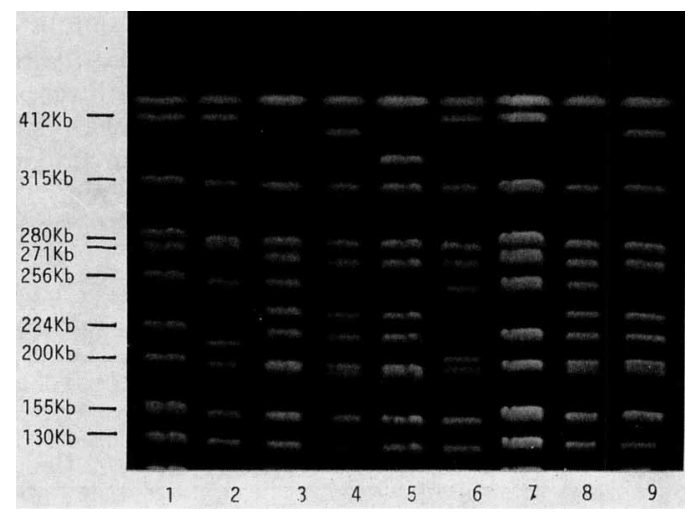

FIG. 1. B. pertussis DNA types 1 through 5 and 9 . Lanes 1 and 7, DNA type 1; lane 2, DNA type 2; lanes 3 and 8, DNA type 3; lanes 4 and 9, DNA type 4; lane 5, DNA type 5; lane 6, DNA type 9. Fragment sizes are indicated on the left. 


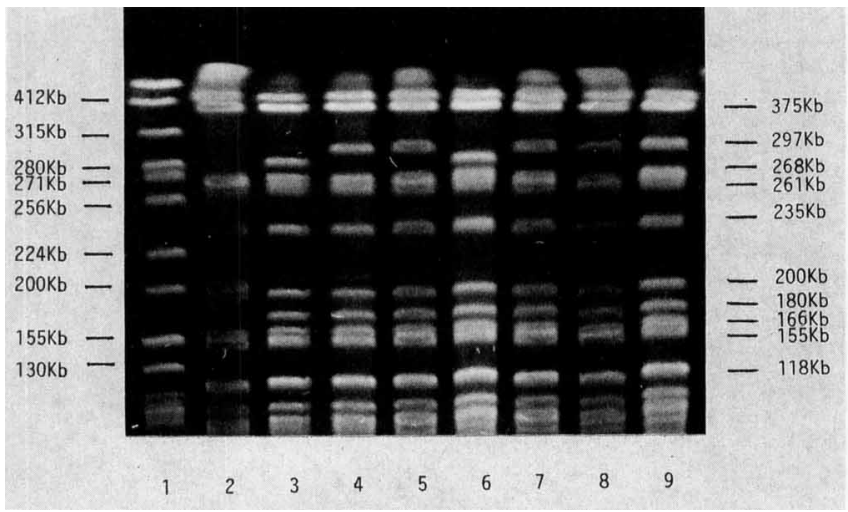

FIG. 2. B. parapertussis DNA types 1 through 3. Lane 1 , molecular weight marker DNA; lanes 4, 5, and 7 through 9, DNA type 1 ; lanes 3 and 6, DNA type 2; lane 2, DNA type 3 . The sizes of fragments are indicated on the right.

isolates with $X b a \mathrm{I}$ generated 9 to 11 large bands in the size range from 118 to $375 \mathrm{~kb}$. A cluster of smaller bands corresponding to sizes less than $97 \mathrm{~kb}$ long was also observed; these bands separated suboptimally under the running conditions selected to resolve the larger bands. Differentiation was based on variation in the four bands at 180 , 200,280 , and $297 \mathrm{~kb}$. For the 10 isolates examined, three different DNA types were defined on the basis of these variable bands (Fig. 2). DNA type 1 predominated; this DNA type was found in 7 of the 10 isolates. There were two DNA type 2 isolates and one DNA type 3 isolate (Table 4). There was no apparent correlation between phenotypic traits and genetic type. Bands at 118, 155, 166, 235, 261, 268, and $375 \mathrm{~kb}$ were conserved.

When the genomes of $B$. bronchiseptica isolates were digested with $X b a I$ under identical conditions, up to 16 large bands in the 118- to $394-\mathrm{kb}$ range were produced along with multiple small bands corresponding to sizes less than $97 \mathrm{~kb}$ long. The DNA typing system was based on variation in the large bands at 118, 166, 200, 230, 240, 250, 256, 261, 268, 297, and $340 \mathrm{~kb}$ (Fig. 3). Five of the eight isolates of $B$. bronchiseptica examined had DNA type 1 , two isolates had DNA type 2, and DNA type 3 was found in only one isolate (Table 5 ). There was no correlation between phenotypic and genotypic differences. Bands at 130, 143, 180, 235, and $394 \mathrm{~kb}$ were conserved.

All of the isolates were typeable by this technique. The reproducibility of the technique was established by repeat testing, which produced identical fingerprint patterns under similar running conditions. Five isolates of each species were tested at least three times, and the repeat fingerprint patterns were unchanged for each of these isolates.

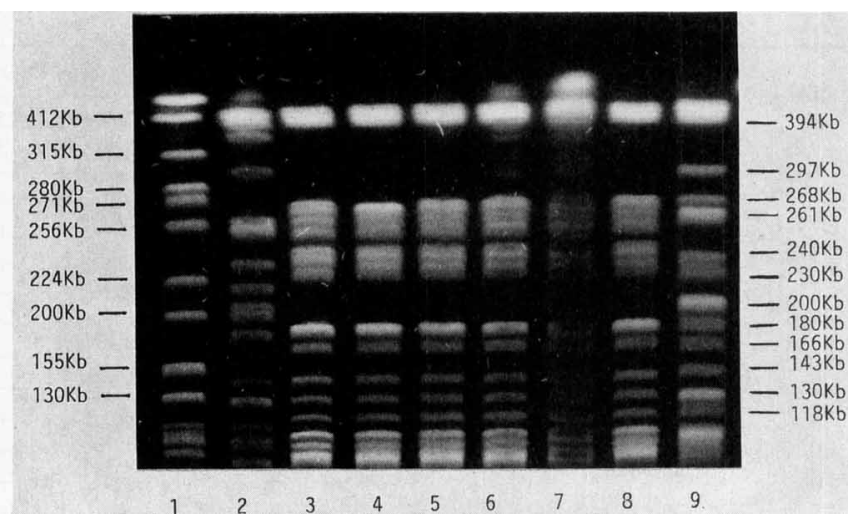

FIG. 3. B. bronchiseptica DNA types 1 through 3. Lane 1 , molecular weight marker DNA; lanes 3 through 8 , DNA type 1 ; lane 2, DNA type 2; lane 9, DNA type 3 . The sizes of fragments are indicated on the right.

\section{DISCUSSION}

The heterogeneity of the three species of the genus Bordetella identified by phenotypic characteristics was demonstrated by the generation of species-specific macrorestriction profiles with the rarely cutting enzyme $X b a I$. The 25 isolates of $B$. pertussis examined in this study produced six different DNA profiles. These isolates were collected between 1940 and 1980 (Table 1). DNA type 1 predominated in this study, accounting for 17 isolates. Among the seven isolates collected before the introduction of pertussis vaccines (Table 1 , up to 1955), five were DNA type 1 isolates. Among the remaining 18 isolates, which were collected after the introduction of mass vaccination, 12 were DNA type 1 isolates. Only one isolate was a DNA type 2 isolate. Four additional DNA types were observed which were different from the 17 DNA types described previously on the basis of an analysis of 105 isolates of $B$. pertussis (6). These new types were designated DNA types 18, 19, 20, and 21 (Table 3 ). The profiles of DNA types 1 to 5 and 9 are shown in Fig. 1. No correlation was found between the serotypes determined by agglutination and the DNA fingerprints determined by PFGE.

All 10 isolates of $B$. parapertussis produced similar DNA fingerprint patterns; 9 to 11 large bands were produced in the size range from 118 to $375 \mathrm{~kb}$, and 7 of these bands $(118,155$, $166,235,261,268$, and $375 \mathrm{~kb}$ ) were conserved. Differentiation within the species was based on four variable bands. The restriction digestion patterns of 7 of the 10 isolates were indistinguishable from each other and were designated $B$. parapertussis DNA type 1 (Fig. 2 and Table 4). Three of these isolates were collected in 1948, 1955, and 1967 from Manchester, United Kingdom. The other four DNA type 1

TABLE 4. Details of $B$. parapertussis DNA types recognized

\begin{tabular}{|c|c|c|c|c|c|c|c|c|c|c|c|c|}
\hline \multirow{2}{*}{$\begin{array}{l}\text { DNA } \\
\text { type }\end{array}$} & \multicolumn{11}{|c|}{ Sizes of DNA fragments ${ }^{a}$} & \multirow{2}{*}{$\begin{array}{l}\text { No. of } \\
\text { isolates }\end{array}$} \\
\hline & $\begin{array}{l}375 \\
\mathrm{~kb}\end{array}$ & $\begin{array}{c}297 \\
\mathrm{~kb}\end{array}$ & $\begin{array}{l}280 \\
\text { kb }\end{array}$ & $\begin{array}{c}268 \\
\mathrm{~kb}\end{array}$ & $\begin{array}{l}261 \\
\text { kb }\end{array}$ & $\begin{array}{c}235 \\
\mathrm{~kb}\end{array}$ & $\begin{array}{l}200 \\
\mathrm{~kb}\end{array}$ & $\begin{array}{l}180 \\
\mathrm{~kb}\end{array}$ & $\begin{array}{l}166 \\
\mathrm{~kb}\end{array}$ & $\begin{array}{l}155 \\
\mathrm{~kb}\end{array}$ & $\begin{array}{l}118 \\
\mathrm{~kb}\end{array}$ & \\
\hline 1 & + & + & - & + & + & + & + & + & + & + & + & 7 \\
\hline 2 & + & - & + & + & + & + & + & + & + & + & + & 2 \\
\hline 3 & + & - & - & + & + & + & DB & - & + & + & + & 1 \\
\hline
\end{tabular}

${ }^{a}+$, band present; - , band absent; DB, double band. 
TABLE 5. Details of B. bronchiseptica DNA types recognized

\begin{tabular}{|c|c|c|c|c|c|c|c|c|c|c|c|c|c|c|c|c|c|}
\hline \multirow{2}{*}{$\begin{array}{l}\text { DNA } \\
\text { type }\end{array}$} & \multicolumn{16}{|c|}{ Sizes of DNA fragments ${ }^{a}$} & \multirow{2}{*}{$\begin{array}{l}\text { No. of } \\
\text { isolates }\end{array}$} \\
\hline & $\begin{array}{l}394 \\
\text { kb }\end{array}$ & $\begin{array}{l}340 \\
\mathrm{~kb}\end{array}$ & $\begin{array}{l}297 \\
\text { kb }\end{array}$ & $\begin{array}{c}268 \\
\mathrm{~kb}\end{array}$ & $\begin{array}{l}261 \\
\mathrm{~kb}\end{array}$ & $\begin{array}{l}256 \\
\text { kb }\end{array}$ & $\begin{array}{l}250 \\
\mathrm{~kb}\end{array}$ & $\begin{array}{l}240 \\
\mathrm{~kb}\end{array}$ & $\begin{array}{l}235 \\
\mathrm{~kb}\end{array}$ & $\begin{array}{c}230 \\
\mathrm{~kb}\end{array}$ & $\begin{array}{l}200 \\
\mathbf{k b}\end{array}$ & $\begin{array}{l}180 \\
\mathrm{~kb}\end{array}$ & $\begin{array}{l}166 \\
\text { kb }\end{array}$ & $\begin{array}{l}143 \\
\mathrm{~kb}\end{array}$ & $\begin{array}{l}130 \\
\mathbf{k b}\end{array}$ & $\begin{array}{l}118 \\
\mathrm{~kb}\end{array}$ & \\
\hline 1 & + & - & - & + & + & + & + & + & + & + & - & + & + & + & + & + & 5 \\
\hline 2 & + & + & + & - & - & + & + & - & + & + & DB & + & - & + & + & - & 2 \\
\hline 3 & + & - & + & + & + & - & - & - & + & - & + & + & + & + & + & + & 1 \\
\hline
\end{tabular}

$a+$, band present; - , band absent; DB, double band.

isolates were from different continents (Table 2). Similarly, the eight isolates of $B$. bronchiseptica produced similar restriction fragment patterns (Fig. 3 and Table 5). Unlike $B$. parapertussis, this species had five conserved bands (at 130 , $143,180,235$ and $394 \mathrm{~kb}$ ), and differentiation was based on 11 variable bands $(118,166,200,230,240,250,256,261,268$, 297 , and $340 \mathrm{~kb}$ ). The restriction fragment patterns of these two species were different from each other even though there was sometimes considerable variation within a species. For example, the $B$. bronchiseptica DNA type 2 pattern (Fig. 3, lane 2) shared just 9 of 16 bands with the $B$. bronchiseptica DNA type 1 or 3 pattern but had only four bands in common with the $B$. parapertussis pattern. Bands at $394,340,256,250,230,143$, and $130 \mathrm{~kb}$ were found in $B$. bronchiseptica DNA type 2 isolates but not in isolates of $B$. parapertussis.

The restriction fragment patterns of these two species were compared with the restriction fragment patterns of 130 isolates of $B$. pertussis obtained in this study and a previous study (6). B. pertussis had two conserved bands (at 130 and $155 \mathrm{~kb}$ ), and differentiation was based on variation in 8 to 11 intense bands between 200 and $412 \mathrm{~kb}$. There was striking interspecies diversity; none of the 130 isolates of $B$. pertussis showed similarity to either of the other two Bordetella species (Fig. 1 through 3). In contrast, PFGE revealed considerable genetic relatedness among strains of the same species.

Multilocus enzyme electrophoresis revealed only a limited degree of genetic diversity among 60 strains of the three Bordetella species. It was concluded that these organisms were related too closely to warrant recognition as three separate species (10). However, multilocus enzyme electrophoresis is a measure of phenotypic expression and measures differences in only a few enzymes (4). Arbeit et al. (1) demonstrated that PFGE could differentiate epidemiologically independent but evolutionarily related isolates of Escherichia coli that were indistinguishable by multilocus enzyme electrophoresis.

Our data confirm that macrorestriction fingerprinting by PFGE of three Bordetella species can identify considerable polymorphism among the species which was missed by multilocus enzyme electrophoresis. Similarly, the results of DNA-DNA hybridization studies suggested that these three species are closely related (7). However, DNA samples indistinguishable on the basis of homology data are not necessarily identical, and DNA samples differing by less than 5\% in homology values cannot be accurately resolved (9).

In conclusion, in this study we found that $B$. pertussis, $B$. parapertussis, and $B$. bronchiseptica had species-specific macrorestriction fingerprints when the organisms were examined by PFGE under the same conditions. Isolates of the same species exhibited various degrees of similarity to each other but were easily distinguishable from the other two species. This heterogeneity in the restriction profiles of the three species, together with the phenotypic differences of the species, argues against the proposal of Kloos et al. (7) and Musser et al. (10) that these organisms should be regarded as members of the same species. Macrorestriction genomic fingerprinting by PFGE reflects the overall organization of the bacterial genome and may for some species be a better indicator of clonal origin and genetic relatedness than data from other types of nucleic acid homology studies (4). It remains to be determined whether further macrorestriction fingerprints generated by other restriction enzymes will generate some fingerprints common to two or more species of the genus Bordetella. Ultimately, genomic maps, such as the one produced for $B$. pertussis by Stibitz and Garletts (17), will help establish the genetic relationships of these three species.

\section{REFERENCES}

1. Arbeit, R. D., M. Arthur, R. Dunn, C. Kim, R. K. Selander, and R. Goldstein. 1990. Resolution of recent evolutionary divergence among Escherichia coli from related lineages: the application of pulsed-field electrophoresis to molecular epidemiology. J. Infect. Dis. 161:230-235.

2. Cheesbrough, M. 1984. Genus Bordetella, p. 280-281. In M. Cheesbrough (ed.), Medical laboratory manual for tropical countries-1983. Cambridge University Press, Cambridge.

3. Finger, H. 1986. Bordetella, p. 540-546. In S. Baron (ed.), Medical microbiology--1986. Addison-Wesley Publishing Co., Reading, Mass.

4. Grothues, D., and B. Tummler. 1991. New approaches in genome analysis by pulsed-field gel electrophoresis: application to the analysis of Pseudomonas species. Mol. Microbiol. 5:2763-2776.

5. Imiazumi, A., Y. Suzuki, S. Ono, H. Sato, and Y. Sato. 1983. Heptakis (2,6-O-dimethyl) $\beta$-cyclodextrin: a novel growth stimulant for Bordetella pertussis phase I. J. Clin. Microbiol. 17:781-786.

6. Khattak, M. N., R. C. Matthews, and J. P. Burnie. 1992. Is Bordetella pertussis clonal? Br. Med. J. 304:813-815.

7. Kloos, W. E., N. Mohapatra, W. J. Dobrogosz, J. W. Ezzell, and C. R. Manclark. 1981. Deoxyribonucleotide sequence relationships among Bordetella species. Int. J. Syst. Bacteriol. 31:173176.

8. McClelland, M., M. R. Jones, Y. Patel, and N. Nelson. 1987. Restriction endonuclease for pulsed field mapping of bacterial genomes. Nucleic Acids Res. 15:5985-6005.

9. McFadden, J. J., and A. Knight. 1991. DNA probes for detection and identification of bacteria, p. 99-111. In J. M. Grange, A. Fox, and N. L. Morgan (ed.), Genetic manipulation. Blackwell Scientific Publications, Oxford.

10. Musser, J. M., E. L. Helwett, M. S. Peppler, and R. K. Selander. 1986. Genetic diversity and relationships in populations of Bordetella spp. J. Bacteriol. 166:230-237.

11. Preston, N. W. 1970. Technical problems in the laboratory diagnosis and prevention of whooping cough. Lab. Pract. 19: $482-486$.

12. Preston, N. W. 1988. Pertussis today, p. 1-18. In A. C. Wardlaw and R. Parton (ed.), Pathogenesis and immunity in pertussis. 
John Wiley and Sons, London.

13. Preston, N. W. 1992. Bordetella: whooping cough, p. 381-388. In D. Greenwood, R. C. B. Slack, and J. F. Peutherer (ed.), Medical microbiology. A guide to microbial infections: pathogenesis, immunity, laboratory diagnosis and control. Churchill Livingstone, Edinburgh.

14. Saunders, N. A. 1991. Analysis of restriction fragment length polymorphisms in the study of bacteria, p. 227-244. In J. M. Grange, A. Fox, and N. L. Morgan (ed.), Genetic manipulation. Blackwell Scientific Publications, Oxford.
15. Smith, C. L., and C. R. Cantor. 1987. Purification, specific fragmentation, and separation of large DNA molecules. Methods Enzymol. 155:449-467.

16. Smith, C. L., S. R. Kalco, and C. R. Cantor. 1988. Pulsed-field gel electrophoresis and the technology of large DNA molecules, p. 41-77. In R. E. Davis (ed.), Genome analysis: a practical approach, 1st ed. IRL Press, Oxford.

17. Stibitz, S., and T. L. Garletts. 1992. Derivation of a physical map of the chromosome of Bordetella pertussis Tohama I. J. Bacteriol. 174:7770-7777. 